\title{
IDENTIFIKASI KELAYAKAN LOKASI LAHAN BUDI DAYA LAUT DI PERAIRAN TELUK SALEH, KABUPATEN DOMPU, NUSA TENGGARA BARAT
}

\author{
Utojo, Abdul Mansyur, Andi Marsambuana Pirzan, Tarunamulia, dan Brata Pantjara
}

\begin{abstract}
ABSTRAK
Nusa Tenggara Barat memiliki sumber daya lahan perikanan pesisir yang cukup potensial untuk pengembangan budi daya laut. Penelitian ini bertujuan untuk menentukan kelayakan lokasi bagi pengembangan budi daya di perairan Teluk Saleh, Kecamatan Empang, Kabupaten Dompu, Nusa Tenggara Barat. Penelitian dilaksanakan dengan menggunakan metode survai. Pengumpulan data sekunder meliputi data iklim, data produksi perikanan, peta rupabumi Indonesia kawasan Sumbawa skala 1:25.000, digital citra landsat-7ETM, dan peta navigasi (batimetri) skala 1:500.000 yang dilakukan sebelum pelaksanaan survai. Data primer diperoleh melalui pengukuran langsung di lapang yang meliputi topografi pantai, keterlindungan, oseanografi, dan biologi. Seluruh lokasi pengambilan contoh ditentukan posisinya dengan Global Positioning System (GPS) dan data yang diperoleh dianalisis dengan menggunakan Sistem Informasi Geografis (SIG). Dari hasil penelitian ini telah diidentifikasi sumber daya lahan perikanan pesisir yang potensial dikembangkan untuk budi daya laut yaitu seluas $1.762,6$ ha. Sumber daya lahan perikanan pesisir yang dinilai sangat layak ( $53,0 \mathrm{ha})$ dan layak ( $346,5 \mathrm{ha})$ untuk budi daya ikan dalam keramba jaring apung terdapat di sebelah timur dan selatan Pulau Rakit dalam kawasan Teluk Saleh, sedangkan yang dinilai sangat layak (181,8 ha) dan layak $(998,7$ ha) untuk budi daya rumput laut terdapat di sebelah barat dan sepanjang pantai Pulau Rakit dalam kawasan Teluk Saleh, dan yang dinilai sangat layak (182,6 ha) untuk budi daya kekerangan terdapat di sebelah utara Pulau Rakit dalam kawasan Teluk Saleh, masing-masing dituangkan dalam peta prospektif skala 1:50.000. Data rinci dan informasi mengenai kelayakan sumber daya lahan untuk budi daya laut, diharapkan dapat dijadikan acuan dalam menentukan prioritas pengembangan bagi penentu kebijakan di dalam pengaturan tata ruang pembangunan di daerah tersebut.
\end{abstract}

ABSTRACT: Identification of potency and suitable location for mariculture in Saleh Bay, Dompu Regency, West Nusa Tenggara. By: Utojo, Abdul Mansyur, Andi Marsambuana Pirzan, Tarunamulia, and Brata Pantjara

\begin{abstract}
West Nusa Tenggara had coastal resources which were potential to be developed for mariculture, however the scientific data support was unavailable. This study was conducted by survey method to find out suitable location to be developed for mariculture in Saleh Bay, Dompu Regency, West Nusa Tenggara. Secondary data such as wheather, coastal fisheries production, Indonesia earth surface map scale 1:25,000, citra landsat-7ETM digital product, and navigation map scale 1:500,000 were collected before the study. The primary data was collected from each study areas and interpreted as mariculture requirement for several domesticated species i.e. fish, seaweed, and mollusca. Tematic map of area suitability as the main expected out put of the study was made through spatial analysis and GIS as suggested by reference. The total potential areas which are suitable for mariculture development are 1,762.6 hectares, namely for fish culture in floating net cage (399.5 hectares), seaweed (1,180.5 hectares), or mollusca (182.6 hectares).
\end{abstract}

KEYWORDS: natural resources, coastal, aquaculture, site selection

\section{PENDAHULUAN}

Perairan di Kawasan Timur Indonesia (KTI) mempunyai potensi yang sangat besar untuk pengembangan budi daya laut. Satu kawasan di antaranya adalah Nusa Tenggara Barat yang memiliki potensi sumber daya lahan budi daya laut masih lestari dan belum dimanfaatkan secara optimal. Potensi tersebut memiliki keunggulan komparatif yang perlu mendapatkan prioritas penanganan agar dapat direalisasikan menjadi keunggulan kompetitif, sehingga peluang peningkatan produksi hasil budi daya di masa mendatang akan semakin besar. Untuk itu diperlukan dukungan penelitian dan iptek yang mantap

Peneliti pada Balai Riset Perikanan Budidaya Air Payau, Maros 
dan lumintu serta ditunjang oleh strategi pemanfaatan sumber daya secara rasional dan berwawasan lingkungan (Sudradjat \& Rachmansyah, 1992) Identifikasi kelayakan sumber daya lahan untuk pengembangan budi daya laut penting artinya dalam rangka penataan ruang daerah yang sesuai dengan peruntukannya sehingga menghindarkan konflik kepentingan baik antar sektor kelautan/perikanan maupun dengan sektor lain. Pemilihan lokasi untuk budi daya laut yang tepat dapat digunakan sebagai indikator awal keberhasilan usaha budi daya sesuai dengan jenis komoditas dan teknologi budi daya yang akan diterapkan (Poernomo, 1988).

Provinsi Nusa Tenggara Barat memiliki dua pulau besar yaitu Lombok dan Sumbawa serta 108 pulau kecil lainnya. Nusa Tenggara Barat memiliki luas wilayah $20.153 \mathrm{~km}^{2}$ dan terletak antara $115^{\circ} 46^{\prime}$ sampai $119^{\circ} 5^{\prime}$ Bujur Timur dan $8^{\circ} 10^{\prime}$ sampai $9^{\circ} 5^{\prime}$ Lintang Selatan (Anonim, 1998). Berdasarkan program Badan Perencanaan dan Pembangunan Daerah dan Dinas Kelautan dan Perikanan Provinsi Nusa Tenggara Barat dan Kabupaten Dompu, wilayah pengembangan budi daya laut dipusatkan di perairan Teluk Saleh, Kabupaten Dompu. Pengembangan wilayah tersebut didasarkan pada ciri-ciri lingkungan budi daya laut, potensi sumber daya hayati laut dan faktor penunjang lainnya.

Kabupaten Dompu berada di wilayah Provinsi Nusa Tenggara Barat, terletak di ujung barat Pulau Sumbawa. Kabupaten tersebut membujur pada posisi $116^{\circ} 42^{\prime}$ sampai $118^{\circ} 22^{\prime}$ Bujur Timur dan $8^{\circ} 8^{\prime}$ sampai $9^{\circ} 7^{\prime}$ Lintang Selatan serta memiliki luas wilayah 1,7 kali luas Pulau Lombok $\left(4.739 \mathrm{~km}^{2}\right)$. Kabupaten Dompu menempati hampir separuh atau $42,4 \%$ dari luas Provinsi Nusa Tenggara Barat yaitu $8.493 \mathrm{~km}^{2}$ (Anonim, 2000). Menurut Hadi et al. (2000), bahwa potensi sumber daya hayati laut di Kabupaten Dompu tidak berbeda dengan potensi yang ada di kabupaten lain di Pulau Lombok. Potensi tersebut antara lain kekerangan (tiram mutiara), rumput laut, ikan, terumbu karang, dan padang lamun. Potensi sumber daya lahan budi daya laut di Kabupaten Dompu seluas 38.720 ha (Anonim, 2000) dan luasan tersebut belum seluruhnya diidentifikasi melalui hasil survai serta prioritas komoditas yang perlu dikembangkan belum terinventarisir secara rinci.

Untuk kegiatan budi daya laut yang berhasil guna dan berdaya guna, maka penentuan lokasi sesuai dengan kondisi perairan, jenis komoditas yang tepat, metode budi daya yang unggul dan dekat dengan pusat konsumen perlu menjadi perhatian. Satu di antara kendala dalam pengembangan budi daya laut di perairan Teluk Saleh, adalah masih terbatasnya data rinci dan informasi mengenai ketepatan kelayakan potensi sumber daya lahan yang dapat dijadikan acuan dalam mengelola sumber daya tersebut secara optimal, belum jelasnya legalitas dan kepastian dalam pemanfaatan kawasan perikanan pesisir untuk budi daya laut. Karena itu, identifikasi, karakterisasi, dan pemetaan sumber daya lahan perikanan pesisir untuk budi daya laut sangat dibutuhkan dalam menentukan skala prioritas dan sasaran komoditas yang akan dikembangkan di wilayah tersebut. Penelitian ini bertujuan untuk menentukan lokasi dan luas sumber daya lahan perikanan pesisir yang layak bagi pengembangan budi daya laut (ikan, rumput laut, dan kekerangan) di perairan Teluk Saleh, Kabupaten Dompu.

\section{BAHAN DAN METODE}

Penelitian dilaksanakan di sepanjang Pulau Rakit dalam kawasan perairan Teluk Saleh, Kecamatan Empang, Kabupaten Dompu sebanyak 2 kali sampling yaitu pada bulan Juli dan November 2001, dengan menggunakan metode survai. Pemilihan lokasi survai ditentukan berdasarkan pada program Badan Perencanaan Pembangunan Daerah (Bappeda) dan Dinas Kelautan dan Perikanan (Dislutkan) Provinsi Nusa Tenggara Barat dan Kabupaten Dompu, mengenai pengembangan wilayah perikanan pesisir untuk penerapan budi daya laut.

Pengumpulan data sekunder meliputi peta rupa bumi Indonesia kawasan Teluk Saleh skala 1:25.000, lembar 2.907-421, edisi I, tahun 1998 yang diperoleh dari Badan Koordinasi Survai dan Pemetaan Nasional (Bakosurtanal), citra land sat-7ETM Digital Product kawasan Teluk Saleh tahun 1999 yang diperoleh dari Lembaga Penerbangan dan Antariksa Nasional (Lapan) dan peta navigasi (batimetri) yang menggambarkan kedalaman laut daerah Teluk Saleh skala 1:500.000, nomor LLN-22 tahun 1992 yang diperoleh dari Dinas Hidro-Oseanografi Angkatan Laut (Dishidros AL) dilakukan sebelum pelaksanaan survai. Peta-peta tersebut digunakan untuk proses analisis awal pembuatan peta dasar digital mulai dari scan atau proyeksi peta, penyusunan dan penggabungan peta melalui digitasi dengan penampilan lokasi survai yang utuh dalam bentuk file vektor dan peta dasar tersebut yang selanjutnya digunakan sebagai peta kerja di lapangan saat survai. Data primer diperoleh melalui pengukuran langsung di lapangan dengan menentukan titik-titik yang berjumlah 15 stasiun pengamatan secara acak dan representatif (Lampiran 1). Setiap stasiun pengamatan ditentukan posisi geografisnya dengan alat Global Positioning System (GPS).

Peubah pokok yang diamati untuk kelayakan lahan budi daya laut meliputi topografi pantai, keterlindungan, oseanografi yang terdiri atas fisik (ombak, arus, pasang surut, kedalaman, dan substrat 
dasar), mutu air ( $\mathrm{pH}$, suhu, salinitas, kekeruhan, kecerahan, pencemar (logam berat: $\mathrm{Pb}, \mathrm{Cd}, \mathrm{Zn}$, dan $\mathrm{Cu}$, DO, $\mathrm{NO}_{3}-\mathrm{N}_{1} \mathrm{NO}_{2}-\mathrm{N}, \mathrm{NH}_{3}-\mathrm{N}$, dan $\mathrm{PO}_{4}-\mathrm{P}$ ), dan biologi (plankton). Peubah tersebut akan digunakan sebagai dasar skala penilaian dan bobot pada kelayakan lahan untuk budi daya laut (ikan, rumput laut, dan kekerangan) dengan mengacu pada persyaratan yang disarankan oleh Ahmad et al. (1991), Mubarak et al. (1990), dan Atjo (1992). Cara mendapatkan skala penilaian dan bobot terhadap kelayakan lahan untuk budi daya laut mengacu pada persyaratan yang disarankan oleh Anonim (1999) terlihat pada Lampiran 1, 2, dan 3 .

Cara mendapatkan skala penilaian dan bobot tersebut adalah sebagai berikut: pembobotan pada setiap faktor pembatas/peubah ditentukan berdasarkan pada dominannya peubah tersebut terhadap suatu peruntukan kelayakan lahan budi daya laut (ikan, rumput laut, dan kekerangan). Kemudian diurutkan faktor-faktor pembatas tersebut dimulai dari yang paling berpengaruh terhadap suatu peruntukan. Bobot terbesar ditentukan 1,00 dan terkecil 0,00. Semua bobot berjumlah 1,00. Dengan demikian, karena jumlah faktor pembatas dalam matriks cukup banyak, maka umumnya setiap faktor tersebut mempunyai bobot berupa pecahan antara 0,00 sampai 1,00 . Untuk setiap faktor pembatas dalam kolom matriks dibuat skala penilaian (rating) dengan angka dari mulai 1 (kurang layak), 2 (cukup layak), 3 (layak), dan 4 (sangat layak). Kemudian dihitung perkalian bobot dengan skala penilaian (rating) untuk menentukan nilai akhir (skor) dari faktor-faktor tersebut. Kemudian dihitung skor total semua faktor pembatas dari setiap kolom skala penilaian (rating) dari mulai 1,00 (kurang layak) sampai 4,00 (sangat layak). Kisaran persentase skala penilaian pada setiap kolom yaitu nilai $4,00(100 \%)=$ S1 (sangat layak); 3,00 (75\%-99\%) = S2 (layak); $2,00(50 \%-74 \%)=\mathrm{S} 3$ (cukup layak); $1,00(<50 \%)=$ $\mathrm{N}$ (kurang layak).

Menurut Hidayat et al. (1995), pengertian skala penilaian (rating) pada setiap kolom adalah sebagai berikut: $\mathbf{S} 1$ (sangat layak), apabila lahan tidak mempunyai pembatas yang berarti untuk mempertahankan tingkat pengelolaan yang harus diterapkan; S2 (layak), apabila lahan mempunyai pembatas agak berarti untuk mempertahankan tingkat pengelolaan yang harus diterapkan; S3 (cukup layak), apabila lahan mempunyai pembatas yang berarti untuk mempertahankan tingkat pengelolaan yang harus diterapkan; $\mathrm{N}$ (kurang layak), apabila lahan mempunyai faktor pembatas cukup berat sehingga mencegah kemungkinan penggunaannya.

Data sekunder dan primer yang sudah dikumpulkan diolah dengan menggunakan analisis spasial dan Sistem Informasi Geografis (SIG) (Purwadhi et al.,
1997), yang bertujuan untuk menentukan kesesuaian lahan budi daya laut dengan komoditas ikan, rumput laut, dan kekerangan. Pada proses analisis tersebut dalam program autocad map, memasukkan data survai dalam peta dasar melalui ploting/overlay pada setiap peubah dengan mempertimbangkan pembobotan dan skala penilaian untuk mendapatkan nilai kesesuaian lahan, dan peta terkini untuk prospek peruntukan sumber daya lahan perikanan pesisir di Teluk Saleh, bagi pengembangan budi daya ikan dalam keramba jaring apung, rumput laut, dan kekerangan.

\section{HASIL DAN BAHASAN}

\section{Kondisi Umum Perairan Teluk Saleh}

Hasil observasi di lapangan, Teluk Saleh merupakan teluk yang kawasan bagian dalamnya terluas dibandingkan dengan beberapa teluk yang berada di Kabupaten Dompu. Di bagian mulut teluk terdapat Pulau Moyo, di dalam Teluk Saleh terdapat beberapa pulau, dan pulau yang terbesar yaitu Pulau Rakit. Di sepanjang pantainya terdapat lekukanlekukan yang merupakan lokasi potensial bagi pengembangan budi daya laut (ikan, rumput laut, dan kekerangan) dan lokasi tersebut terlindung dari arus yang kuat. Topografi daratan Pulau Rakit yaitu datar sampai berbukit, sedangkan hasil penelitian mengenai kondisi perairannya yang dilakukan sebanyak 2 kali sampling yaitu pada bulan Juli dan November 2001 antara lain dasar perairan umumnya mempunyai kemiringan berkisar $35^{\circ}-60^{\circ}$; kedalaman air $7-30$ $\mathrm{m}$; tinggi ombak $9,0-30,0 \mathrm{~cm}$; dan periode ombak $2,4-5,9$ detik; kecepatan arus $3,2-23,8 \mathrm{~cm} /$ detik; dan substrat dasar perairannya terdiri atas pasir $(23 \%-85 \%)$, lempung $(0 \%-8 \%)$, debu $(15 \%-70 \%)$, dan pecahan karang $(100 \%)$.

Pada umumnya di Provinsi Nusa Tenggara Barat beriklim tropis, di mana musim timur terjadi dari bulan Oktober sampai dengan Maret bertepatan dengan musim hujan dan kondisi angin bertiup dari arah timur ke barat yang umumnya berkekuatan kecil sampai sedang. Sedangkan musim barat terjadi dari bulan April sampai dengan September bertepatan dengan musim kemarau dan kondisi angin bertiup dari arah barat ke timur yang umumnya berkekuatan besar. Kondisi angin tersebut sangat berpengaruh terhadap pergerakan ombak dan arus di perairan Teluk Saleh.

Pola pergerakan arus permukaan yang masuk di perairan Teluk Saleh, di samping dipengaruhi oleh pola arus yang terjadi dari pecahan ombak di perairan Laut Flores dan Jawa, juga oleh kondisi pasang surut di perairan Teluk Saleh dan sekitarnya. Arus yang bergerak dari arah utara (Laut Flores) ke selatan tertahan oleh Pulau Moyo dan Rakit serta beberapa 
pulau kecil lainnya, sedangkan yang datang dari arah barat dan timur tertahan oleh Pulau Sumbawa sehingga kecepatan arus sampai di dalam perairan Teluk Saleh berkisar 3,2-23,8 cm/detik dan tinggi ombak 9,0-30,0 cm.

Dengan melihat pola pergerakan arus dan ombak tersebut, lokasi yang potensial untuk pengembangan budi daya laut yaitu di kawasan sekitar Pulau Rakit yang terletak di dalam Teluk Saleh.

Menurut Ahmad et al. (1996), pengembangan usaha budi daya perikanan pesisir berbasis budi daya laut dapat dilakukan pada kawasan pesisir seperti selat, teluk, laguna, dan muara sungai yang terlindung dari pengaruh arus kuat, gelombang besar, angin yang kencang, serta bebas cemaran. Selanjutnya menurut Cholik et al. (1995), ekosistem teluk, selat, goba, dan muara sungai umumnya merupakan lokasi bagi budi daya ikan, sedangkan dataran pasang surut yang landai dengan dasar batu-batuan, sisa-sisa karang, dan pasir dapat dijadikan lokasi bagi budi daya rumput laut. Lokasi yang baik bagi budi daya kekerangan umumnya adalah dataran pasang surut lumpur berpasir. Perairan estuarin juga baik bagi budi daya kekerangan seperti tiram dan kerang hijau.

\section{Potensi Kelayakan Lokasi Budi Daya Laut}

Satu di antara keberhasilan usaha budi daya laut, diawali dengan pemilihan kelayakan lokasi dan luas lahan budi daya menentukan estimasi jumlah unit keramba/rakit yang dapat tertampung di areal tersebut sesuai dengan komoditas yang dikelolanya dan daya dukung lahan. Dalam mengidentifikasi kebutuhan teknologi budi daya laut didasarkan pada karakteristik wilayah perairan Teluk Saleh, dan masukan Bappeda serta Diskanlut Provinsi Nusa Tenggara Barat dan Kabupaten Dompu. Berdasarkan hasil survai fisik oseanografi dan mutu air di perairan Teluk Saleh untuk potensi pengembangan budi daya laut yang dilakukan sebanyak 2 kali sampling yaitu pada bulan Juli dan November 2001 terlihat pada Tabel 1 dan Lampiran 4.

Tabel 1. Hasil pengukuran fisik dan mutu air Teluk Saleh, Kabupaten Dompu, Nusa Tenggara Barat Table 1. Measurement resulted of physical and water quality of Saleh Bay, Dompu Regency, West Nusa Tenggara

\begin{tabular}{|c|c|}
\hline $\begin{array}{c}\text { Peubah fisik dan mutu air } \\
\text { Variables of physical and water quality }\end{array}$ & $\begin{array}{l}\text { Kisaran } \\
\text { Range }\end{array}$ \\
\hline Tinggi ombak (Wave hight) $(\mathrm{cm})$ & $9.0--30.0$ \\
\hline Kecepatan arus (cm/detik) (Current) $(\mathrm{cm} / \mathrm{sec}$.) & $3.2-23.8$ \\
\hline Pasang surut $($ Tide $)(\mathrm{cm})$ & 114 \\
\hline Kedalaman $($ Depth $)(\mathrm{m})$ & 4.1--25.3 \\
\hline \multicolumn{2}{|l|}{ Substrat (Substrate) (\%): } \\
\hline Pasir (Sand) & $23.0-85.0$ \\
\hline Lempung (Clay) & 0--8.0 \\
\hline Debu (Silt) & $15.0--70.0$ \\
\hline Pecahan karang (Coral fragment) & 100 \\
\hline $\mathrm{pH}$ & $8.1--8.4$ \\
\hline Suhu (Temperature) $\left({ }^{\circ} \mathrm{C}\right)$ & $29.0--30.7$ \\
\hline Salinitas (Salinity) (ppt) & $34.5--35.0$ \\
\hline Kekeruhan (Turbidity) (NTU) & $0.11-40.79$ \\
\hline Kecerahan (Transparency) $(\%)$ & 53.9--97.6 \\
\hline Oksigen terlarut (Dissolved oxygen) (mg/L) & $7.0-8.2$ \\
\hline $\mathrm{NH}_{3}-\mathrm{N}(\mathrm{mg} / \mathrm{L})$ & $0.0520-0.1270$ \\
\hline $\mathrm{NO}_{2}-\mathrm{N}(\mathrm{mg} / \mathrm{L})$ & $0.0102--0.0261$ \\
\hline $\begin{array}{l}\mathrm{NO}_{2}-\mathrm{N}(\mathrm{mg} / \mathrm{L}) \\
\mathrm{NO}_{3}-\mathrm{N}(\mathrm{mg} / \mathrm{L})\end{array}$ & $0.0309--0.1883$ \\
\hline $\begin{array}{l}\mathrm{PO}_{4}-\mathrm{P}(\mathrm{mg} / \mathrm{L}) \\
\text { Logam berat }(\text { Heavy metal) }(\mathrm{mg} / \mathrm{L}) \text { : }\end{array}$ & $0.0059-0.0325$ \\
\hline \multicolumn{2}{|l|}{$\begin{array}{l}\text { Logam berat (Heavy metal) (mg/L): } \\
\text { Log }\end{array}$} \\
\hline $\begin{array}{l}\text { Kadmium (Cadmium) (Cd) } \\
\text { Tembaga (Cuprum) }(\mathrm{Cu})\end{array}$ & $0.0035-0.0039$ \\
\hline $\begin{array}{l}\text { Tembaga (Cuprum) }(\mathrm{Cu}) \\
\text { Timbal (Plumbum) }(\mathrm{Pb})\end{array}$ & $0.0003--0.0045$ \\
\hline $\begin{array}{l}\text { Timbal (Plumbum) (Pb) } \\
\text { Seng (Zinc) }(\mathrm{Zn})\end{array}$ & $0.0087--0.0096$ \\
\hline & $0.0361--0.0634$ \\
\hline
\end{tabular}


Beberapa peubah fisik oseanografi yang sangat penting peranannya dalam menentukan lokasi budi daya antara lain gerakan ombak dan arus serta kedalaman. Gerakan ombak yang besar dengan pengaruh mekaniknya pada saat pelaksanaan budi daya dapat menghancurkan dan menghanyutkan konstruksi rakit, keramba, hampang, dan fasilitas penunjang lainnya. Tinggi ombak di perairan teluk berkisar 9,0-30,0 cm mempunyai kekuatan yang relatif kecil sehingga dapat menghantarkan gas-gas oksigen bebas dari atmosfer ke dalam air melalui proses defusi yang selanjutnya dapat meningkatkan kandungan oksigen terlarut dalam air, dan dapat memberikan transfer energi melalui partikel air yang sesuai dengan arah hembusan (As'ad, 2000).

Menurut Ahmad et al. (1991), kondisi lingkungan seperti amplitudo pasang dan gelombang yang baik untuk usaha budi daya ikan dalam keramba jaring apung di laut kurang dari 2 meter. Arus air sangat penting untuk menjaga media budi daya selalu dalam kondisi optimum, yang berfungsi sebagai transportasi massa air sekaligus membersihkan kotoran, mendistribusikan kandungan oksigen terlarut dan unsur hara secara merata serta dapat mengurangi organisme penempel (fouling).

Kecepatan arus di perairan teluk berkisar 3,2$23,8 \mathrm{~cm} /$ detik masih dalam kisaran layak untuk usaha budi daya. Menurut Ahmad et al. (1991), kecepatan arus yang baik untuk usaha budi daya ikan dalam keramba jaring apung berkisar $5-15 \mathrm{~cm} /$ detik. Selanjutnya lokasi yang diinginkan untuk budi daya rumput laut yaitu mempunyai gerakan air yang cukup untuk membawa unsur hara dengan kecepatan arus berkisar 20-40 cm/detik (Mubarak et al., 1990). Arah arus perlu diketahui untuk menentukan gambaran umum wadah budi daya sehingga sirkulasi air tetap lancar dan terkendali.

Substrat dasar perairan teluk terdiri atas pasir $(23 \%-85 \%)$, lempung $(0 \%-8 \%)$, debu $(15 \%-70 \%)$, dan pecahan karang (100\%). Kondisi dasar perairan tersebut penting dalam menentukan jenis dan ukuran jangkar serta jarak dari keramba ke dasar untuk menghindari kekeruhan akibat adanya arus bawah. Menurut Mayunar et al. (1995), dalam usaha budi daya ikan dalam keramba jaring apung, desain dan konstruksi keramba harus disesuaikan dengan kecepatan arus dan kondisi dasar perairan (lumpur, pasir, dan karang).

Kedalaman air dipengaruhi oleh perubahan pasang dan kontur dasar perairan, sangat penting peranannya dalam menentukan metode budi daya yang diterapkan dan komoditas yang dikelola. Kedalaman air di teluk berkisar 4,1-25,3 m. Nilai kisaran kedalaman pada kawasan tersebut masih dalam batas potensial dikembangkan untuk berbagai metode budi daya. Dengan demikian kisaran kedalaman air yang terukur di daerah ini potensial dikembangkan untuk usaha budi daya ikan dalam keramba jaring apung, budi daya kekerangan dalam jaring tancap atau hampang, dan budi daya rumput laut dengan menggunakan rakit terapung. Menurut Ahmad et al. (1991), kedalaman air laut yang layak untuk kegiatan budi daya ikan dalam keramba jaring apung lebih dari $5 \mathrm{~m}$. Untuk usaha budi daya yang menggunakan keramba jaring apung memerlukan jarak paling sedikit $1 \mathrm{~m}$ dari keramba ke dasar perairan (Sunyoto, 1994). Usaha budi daya menggunakan jaring tancap (lola) memerlukan kedalaman sekitar $0,5 \mathrm{~m}$ pada saat surut terendah.

Mutu air laut sebagai media budi daya, kondisinya selalu berfluktuasi tergantung atau sangat dipengaruhi oleh perubahan pasang dan musim. Peubah media budi daya yang lama berpengaruh terhadap kondisi perairan laut adalah logam berat karena merupakan pencemar atau limbah dari industri yang dapat terakumulasi di dalam badan komoditas budi daya dan di lingkungan serta dasar perairan. Di kawasan pesisir Teluk Saleh umumnya bukan merupakan daerah industri dan penduduk yang hidup di kawasan tersebut relatif sedikit. Hal ini terlihat dari hasil analisis logam berat (Tabel 1 dan Lampiran 5) di perairan teluk yang terdiri atas unsur kadmium (Cd) berkisar 0,0035-0,0039 mg/L; tembaga (Cu) 0,0003-0,0045 $\mathrm{mg} / \mathrm{L}$; timbal $(\mathrm{Pb})$ 0,0087-0,0096 mg/L; dan seng (Zn) 0,0361-0,0634 mg/L, masih aman dan memenuhi syarat untuk kegiatan budi daya laut sesuai yang dianjurkan oleh KLH (1988) yaitu unsur kadmium (Cd) yang diperbolehkan lebih kecil dari 0,01 mg/L; untuk unsur tembaga $(\mathrm{Cu})$ yang diperbolehkan lebih kecil 0,06 $\mathrm{mg} / \mathrm{L}$; dan untuk unsur seng $(\mathrm{Zn})$ yang diperbolehkan lebih kecil 0,1 mg/L; serta untuk unsur timbal $(\mathrm{Pb})$ yang diperbolehkan lebih kecil 0,01 mg/L.

Jenis plankton yang merupakan bagian dari media budi daya di perairan teluk terdiri atas 26 spesies fitoplankton. Kelimpahan fitoplankton yang tertinggi (2.730 ind. $/ \mathrm{mL}$ ) diperoleh dari Chineto sp., kemudian Oscillatoria sp. (560-1.830 ind./mL), dan Chaetoceros sp. (730-2.510 ind./mL). Pada dasarnya peranan organisme plankton penting artinya untuk penilaian terhadap kondisi perairan dan potensi sumber daya lautnya untuk pengembangan kegiatan budi daya kekerangan.

Dari hasil penilaian tingkat kelayakan lokasi budi daya laut (ikan, rumput laut, dan kekerangan) di Teluk Saleh (Lampiran 8) menunjukkan bahwa sumber daya lahan perikanan pesisir yang potensial dikembangkan untuk budi daya laut seluas $1.762,6$ ha. Yang dinilai sangat layak (53,0 ha) dan layak (346,5 ha) untuk budi daya ikan dalam keramba jaring apung terdapat di sebelah timur dan selatan Pulau Rakit 
dalam kawasan Teluk Saleh. Jumlah keramba yang diperkirakan dapat dialokasikan dalam kawasan seluas 400 ha sebanyak 20.000 unit, di mana setiap hektarnya dapat ditempatkan rakit sebanyak 50 unit dan setiap rakitnya terdiri atas 4 unit keramba berukuran $2 \times 2 \times 2 \mathrm{~m}^{3}$. Lahan yang dinilai sangat layak ( 181,8 ha) dan layak ( 998,7 ha) untuk budi daya rumput laut terdapat di sebelah barat dan sepanjang pantai Pulau Rakit dalam kawasan Teluk Saleh. Jumlah rakit yang diperkirakan dapat dialokasikan dalam kawasan seluas 1.180 ha sebanyak 118.000 unit, di mana setiap hektarnya dapat ditempatkan rakit sebanyak 100 unit yang setiap rakitnya berukuran 5 $x 2,5 \mathrm{~m}^{2}$. Yang dinilai sangat layak (182,6 ha) untuk budi daya kekerangan terdapat di sebelah utara Pulau Rakit dalam kawasan Teluk Saleh. Jumlah hampang yang diperkirakan dapat dialokasikan dalam kawasan seluas 182 ha sebanyak 18.200 unit, di mana setiap hektarnya dapat ditempatkan hampang sebanyak 100 unit yang setiap hampang berukuran $4 \times 4 \mathrm{~m}^{2}$.

\section{Prioritas Tahapan Kegiatan Usaha Budi Daya Laut yang Akan Diaplikasikan}

Sebagai tahapan awal yang mudah dan segera dapat dikerjakan atau diperkenalkan adalah budi daya rumput laut jenis Eucheuma sp. sebagai bahan untuk pembuatan karaginan ataupun jenis Gracilaria sp. sebagai bahan pembuatan agar-agar. Metode budi dayanya cukup mudah dan murah yaitu dengan metode apung (raft method) menggunakan rakit atau tali gantung (kedalaman teluk 4,1-25,3 m) dengan investasi yang terjangkau dan dapat diadopsi dengan baik oleh masyarakat nelayan. Berdasarkan tingkat produktivitas yang tinggi sekitar $20 \mathrm{~kg}$ rumput laut kering/rakit $\left(5 \times 2,5 \mathrm{~m}^{2}\right)$ dan siklus periode pemeliharaan yang relatif singkat sekitar 45 hari setelah tanam, maka rumput laut dapat dikembangkan dengan mudah dalam skala komersial untuk mendukung kegiatan agroindustri. Dengan mempertimbangkan peluang yang ada, maka bila setiap rumah tangga nelayan memiliki 10 unit rakit (5 $\times 2,5 \mathrm{~m}^{2}$ ) dengan jumlah frekuensi tanam sebanyak 8 musim setahun dan harga jual Rp $3.000,-/ \mathrm{kg}$ kering, maka setiap keluarga nelayan akan memperoleh pendapatan sebanyak Rp 4.800.000,-/tahun atau Rp $400.000,-/$ bulan, suatu usaha yang cukup layak sebagai sumber pendapatan masyarakat nelayan (Rachmansyah et al., 1999). Pada umumnya jenis Gracilaria verrucosa dan Gelidium latifolium dikonsumsi oleh industri agar lokal dan industri rumah tangga di Jawa bagian timur, sedangkan jenis Kappaphycus alvarezii dan Eucheuma denticulatum digunakan dalam industri karaginan yang dikonsumsi oleh eksportir di Bali dan Lombok (Hatta \& Dahoklory, 1996). Selain budi daya rumput laut, juga dapat diusahakan budi daya kekerangan (abalon dan tiram mutiara) dengan metode dasar (bottom method) metode hampang (pen culture), dan metode apung (raft method).

Tahapan berikutnya (kedua) adalah usaha budi daya laut yang memerlukan modal lebih besar dan pengetahuan yang lebih luas, yaitu budi daya ikan menggunakan keramba jaring apung (KJA) Dibutuhkan modal lebih besar, karena selain untuk pembuatan rakit dan keramba jaring, juga dibutuhkan pengeluaran biaya untuk pakan. Komoditas yang dipelihara dalam KJA harus ekonomis penting seperti satu di antaranya adalah ikan kerapu (Epinephelus $\mathrm{sp}$.). Data yang ada menunjukkan bahwa usaha budi daya ikan dalam KJA ukuran $3 \times 3 \times 3 \mathrm{~m}^{3}$ dengan padat penebaran $50 \mathrm{ekor} / \mathrm{m}^{3}$, memerlukan investasi sebesar Rp 7.228.100,- dan biaya operasional Rp 20.405.200,- dengan hasil produksi 2 kali setahun mencapai Rp 25.824.600,- sehingga keuntungan kotor yang dicapai selama satu tahun sebesar Rp 5.419.400,- (Ahmad et al., 1995). Untuk ketiga jenis usaha tersebut (rumput laut, kekerangan, dan ikan dalam KJA), benih yang dibutuhkan sepenuhnya diperoleh dari alam (benih alam). Oleh karena itu dalam pengembangan budi dayanya, kelestarian ekosistemnya harus dijaga dan satu di antaranya melalui kelayakan lokasi budi daya

\section{KESIMPULAN}

Sumber daya lahan perikanan pesisir di Teluk Saleh, Kabupaten Dompu yang potensial dikembangkan untuk budi daya laut seluas $1.762,6$ ha. Penilaian sumber daya lahan tersebut yang tergolong sangat layak dan layak untuk lokasi budi daya ikan dalam keramba jaring apung seluas 53,0 ha dan 346,5 ha; terdapat di sebelah timur dan selatan Pulau Rakit dalam kawasan Teluk Saleh. Lahan yang tergolong sangat layak dan layak untuk lokasi budi daya rumput laut seluas 181,8 ha dan 998,7 ha; terdapat di sebelah barat dan sepanjang pantai Pulau Rakit dalam kawasan Teluk Saleh, dan yang tergolong sangat layak untuk lokasi budi daya kekerangan seluas 182,6 ha, terdapat di sebelah utara Pulau Rakit dalam kawasan Teluk Saleh. Kondisi oseanografi perairan lautnya sebagai media budi daya masih layak, aman, dan mendukung kegiatan budi daya.

\section{DAFTAR PUSTAKA}

Ahmad, T., P.T. Imanto, Muchari, A. Basyarie, P. Sunyoto, B. Slamet, Mayunar, R. Purba, S. Diana, S. Redjeki, A.S. Pranowo, dan S. Murtiningsih. 1991. Operasional pembesaran ikan kerapu dalam keramba jaring apung. Laporan Teknis Balai Penelitian Perikanan Budidaya Pantai, Maros, 59 pp.

Ahmad, T., A. Mustafa, dan A. Hanafi. 1996. Konsep pengembangan desa pantai mendukung 
keberlanjutan produksi perikanan pesisir. Dalam Poernomo, A., H.E. Irianto, S. Nurhakim, Murniyati, dan E. Pratiwi (Eds.). Prosiding Rapat Kerja Teknis Peningkatan Visi Sumberdaya Manusia Peneliti Perikanan Menyongsong Globalisasi IPTEK, Serpong 19-20 November 1996. Badan Litbang Pertanian, Puslitbang Perikanan, Jakarta, p. 91-106.

Ahmad, T., A. Rukyani, dan A. Wijono. 1995. Teknik budidaya laut dengan keramba jaring apung dalam Sudradjat, A., W. Ismail, B. Priono, Murniyati, dan E. Pratiwi (Eds.). Prosiding Temu Usaha Pemasyarakatan Teknologi Keramba Jaring Apung Bagi Budidaya Laut, Jakarta, 12-13 April 1995. Badan Litbang Pertanian, Puslitbang Perikanan, Jakarta, p. 69-87.

Anonim. 1998. Nusa Tenggara Barat dalam Angka (Nusa Tenggara Barat in Figures). Kerjasama Badan Pusat Statistik (BPS) Propinsi Nusa Tenggara Barat dengan Badan Perencanaan dan Pembangunan Daerah (BAPPEDA) Propinsi Nusa Tenggara Barat, 501 pp.

Anonim. 1999. Pedoman Analisis SWOT. Proyek Pengkajian Teknologi Pertanian Partisipatif. Badan Penelitian dan Pengembangan Pertanian, Jakarta, 17 pp.

Anonim. 2000. Dompu dalam Angka (Dompu in Figures). Kerjasama Badan Pusat Statistik (BPS) Kabupaten Dompu dengan Badan Perencanaan Pembangunan Daerah (BAPPEDA) Kabupaten Dompu, 521 pp.

As'ad, M. 2000. Abrasi Pantai Biringkasi. Maccini Baji, Kecamatan Bungoro, Labakkang Kabupaten Pangkep. Skripsi Jurusan IImu Kelautan, Fakultas IImu Kelautan dan Perikanan, Universitas Hasanuddin, Makassar, $70 \mathrm{pp}$.

Atjo, H. 1992. Potensi sumber daya kekerangan Kabupaten Barru dalam Mansur, H., Rachmansyah, A. Mustafa, dan A.M. Pirzan (Eds.). Prosiding Temu Karya Ilmiah Potensi Sumberdaya Kekerangan Sulawesi Selatan dan Sulawesi Tenggara, No. 7. 1992, Watampone, 17-18 Februari 1992, p. 8-10.

Cholik, F., A. Sudradjat, dan P.T. Imanto. 1995. Peluang agribisnis budidaya laut di Kawasan Timur Indonesia. Dalam A. Sudradjat, W. Ismail, B. Priono, Murniyati, dan E. Pratiwi (Eds.). Prosiding Temu Usaha Pemasyarakatan Teknologi Keramba Jaring Apung Bagi Budidaya Laut, Jakarta, 12-13 April 1995. Badan Litbang Pertanian, Puslitbang Perikanan, Jakarta, p. 136-156.

Hadi, S., J. Pariwono, A. Purbayanto, S. Sardono, F. Yulianda, J. Bachri, Y. Rustandi, dan Y. Wahyuddin. 2000. Atlas Sumberdaya Wilayah Pesisir dan Laut Propinsi Nusa Tenggara Barat. Kerjasama antara Badan Perencanaan Pembangunan Daerah (BAPPEDA) Propinsi Nusa Tenggara Barat dengan Pusat Kajian Sumberdaya Pesisir dan Lautan (PKSPL) Institut Pertanian Bogor (IPB), Bogor, 117 pp.
Hidayat, A., M. Soekardi, dan Ponidi. 1995. Kajian kesesuaian lahan untuk mendukung pembangunan perikanan pantai dan pertanian di daratan KasiputeLainea, Sulawesi Tenggara. Dalam Laporan Akhir Hasil Penelitian Potensi dan Hasil Kesesuaian Lahan untuk Pengembangan Perikanan Pantai (Tingkat Tinjau Mendalam) Daerah Kasipute-Lainea, Sulawesi Tenggara. Pusat Penelitian Tanah dan Agroklimat Bekerjasama dengan Proyek Pembinaan Kelembagaan Penelitian Pertanian Nasional, Jakarta, p. 96-162.

Hatta, A.M. and G.M.B.K. Dahoklory. 1996. Seaweed-based economic activities in Lombok and Bali, Indonesia. Naga The ICLARM Quarterly, 2(19): 18-21.

Kependudukan dan Lingkungan Hidup (KLH). 1988. Lampiran VII dan VIII Surat Keputusan Menteri Negara Kependudukan dan Lingkungan Hidup No. KEP-02/ MENKLH//1998, tanggal 19 Januari 1988 tentang Baku Mutu Air untuk Perikanan dan Taman Laut Konservasi, 2 pp.

Mayunar, R. Purba, dan P.T. Imanto. 1995. Pemilihan lokasi untuk usaha budidaya ikan laut. Dalam Sudradjat, A., W. Ismail, B. Priono, Murniyati, dan E. Pratiwi (Eds.). Prosiding Temu Usaha Pemasyarakatan Teknologi Keramba Jaring Apung bagi Budidaya Laut, Jakarta, 12-13 April 1995, p. 179-189.

Mubarak, H., S. llyas, I.S. Wahyuni, S.H. Hartati, E. Pratiwi, Z. Jangkaru, dan A. Arifudin. 1990. Petunjuk Teknis Budi Daya Rumput Laut. Badan Penelitian dan Pengembangan Pertanian, Pusat penelitian dan Pengembangan Perikanan, IDRC, Infish, 93 pp.

Poernomo, A. 1988. Pembuatan Tambak Udang di Indonesia. Seri Pengembangan No. 7, 1988. Departemen Pertanian, Badan Penelitian dan Pengembangan Pertanian, Balai Penelitian Perikanan Budidaya Pantai, Maros, 30 pp.

Purwadhi, S. Hardiyanti, Susanto, dan Hidayat. 1997. Penggunaan data inderaja satelit dan sistem informasi geografis (SIG) untuk perencanaan dan pengelolaan tata ruang wilayah. Dipresentasikan dalam Seminar Open House LAPAN dalam Rangka Tahun Kebangkitan IPTEK Nasional Jakarta, 5-7 Agustus 1997, $21 \mathrm{pp}$.

Sudradjat, A. dan Rachmansyah. 1992. Status pengelolaan sumberdaya perikanan budidaya pantai di Kawasan Timur Indonesia. Dalam Poernomo, A., R. Arifuddin, dan T. Wikanta (Eds.). Prosiding Lokakarya Pengkajian Peluang dan Tantangan Perikanan Kawasan Timur Indonesia. Ujung Pandang, 18-20 Juni 1992. Badan Penelitian dan Pengembangan Pertanian, Pusat Penelitian dan Pengembangan Perikanan, p. 106-119.

Sunyoto, P. 1994. Pembesaran Kerapu dengan Keramba Jaring Apung. Penebar Swadaya, Jakarta, 65 pp. 


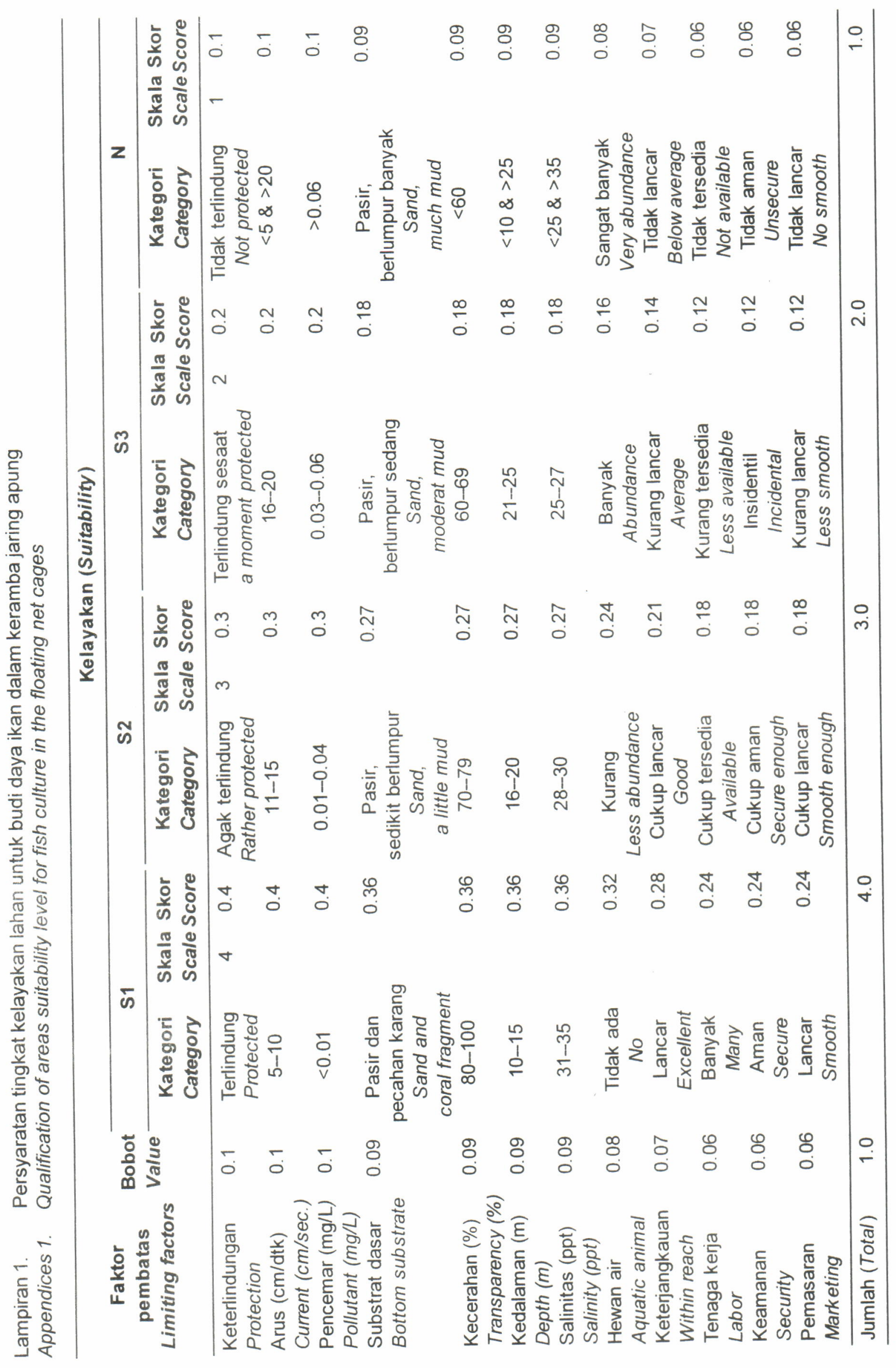


Jurnal Penelitian Perikanan Indonesia Volume 10 Nomor 5 Tahun 2004

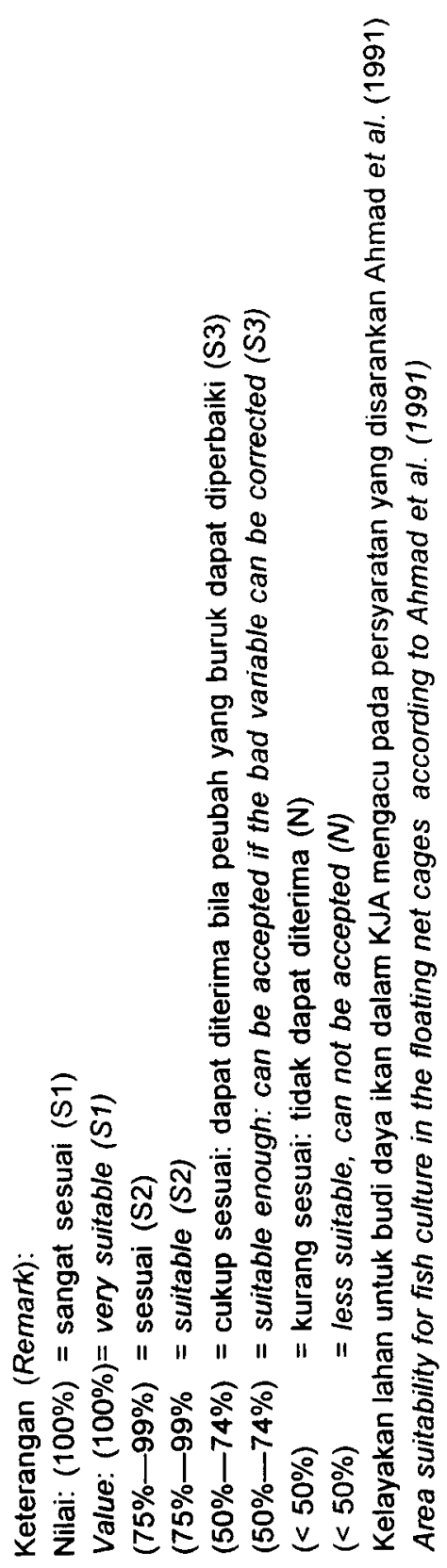




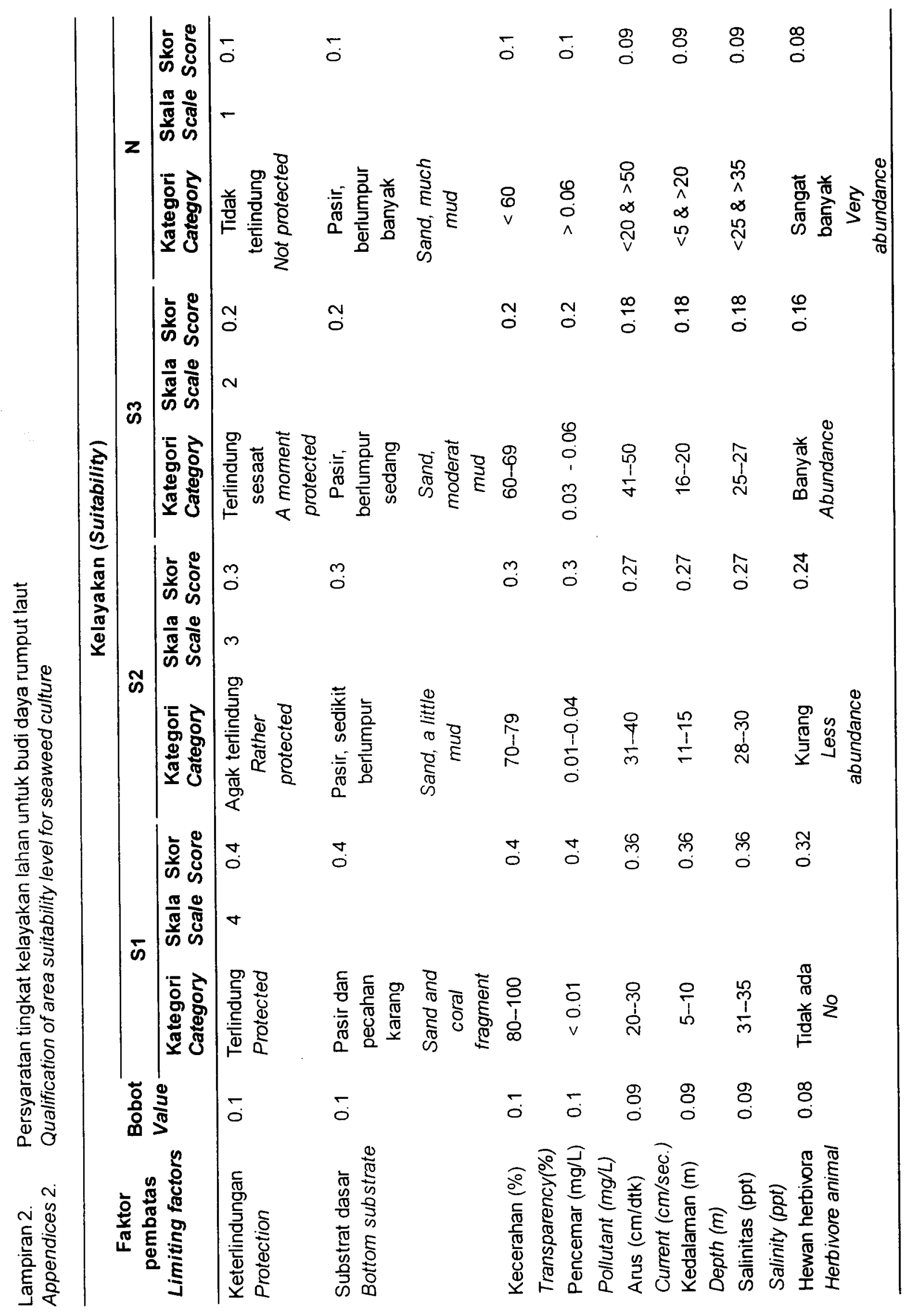




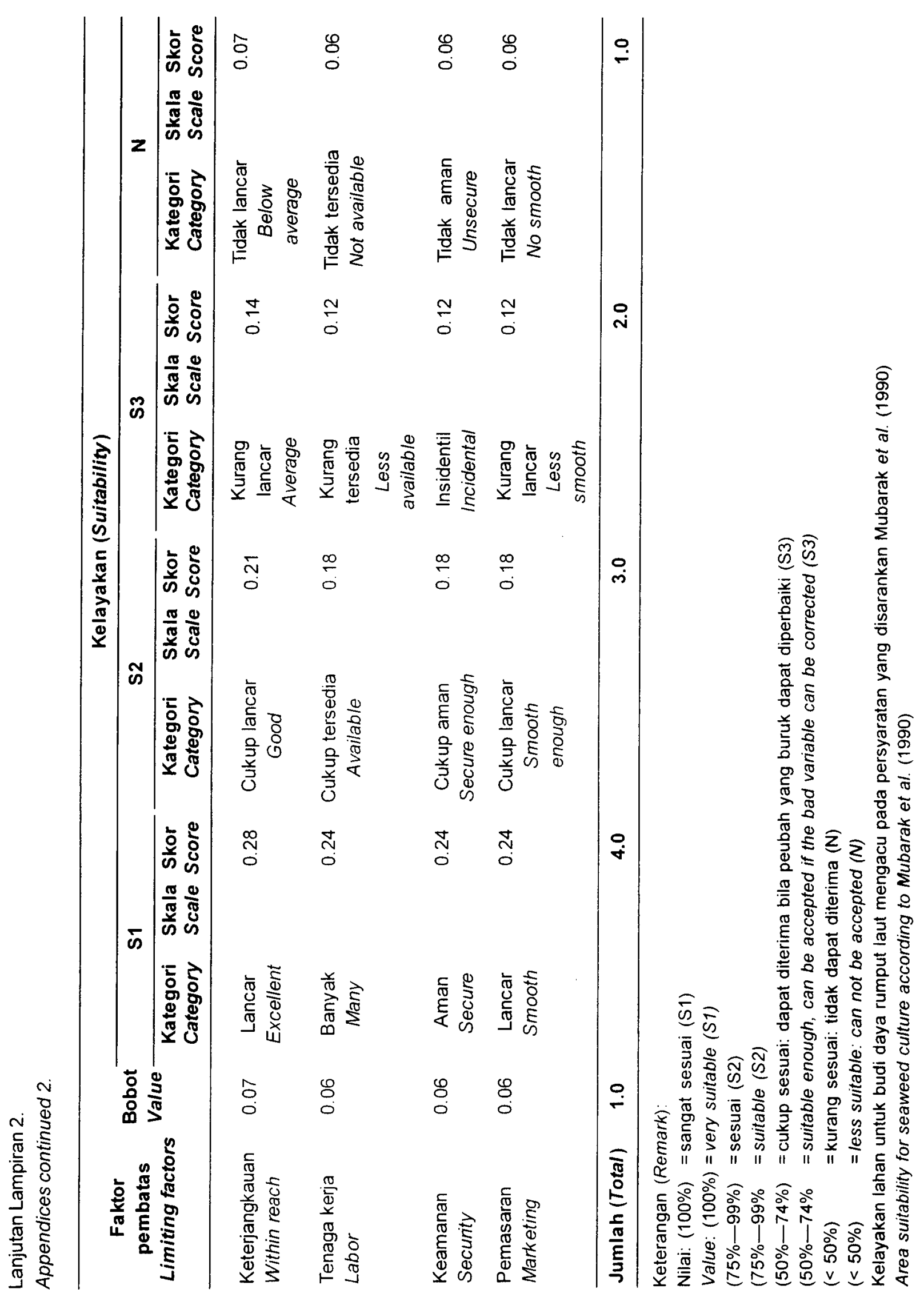




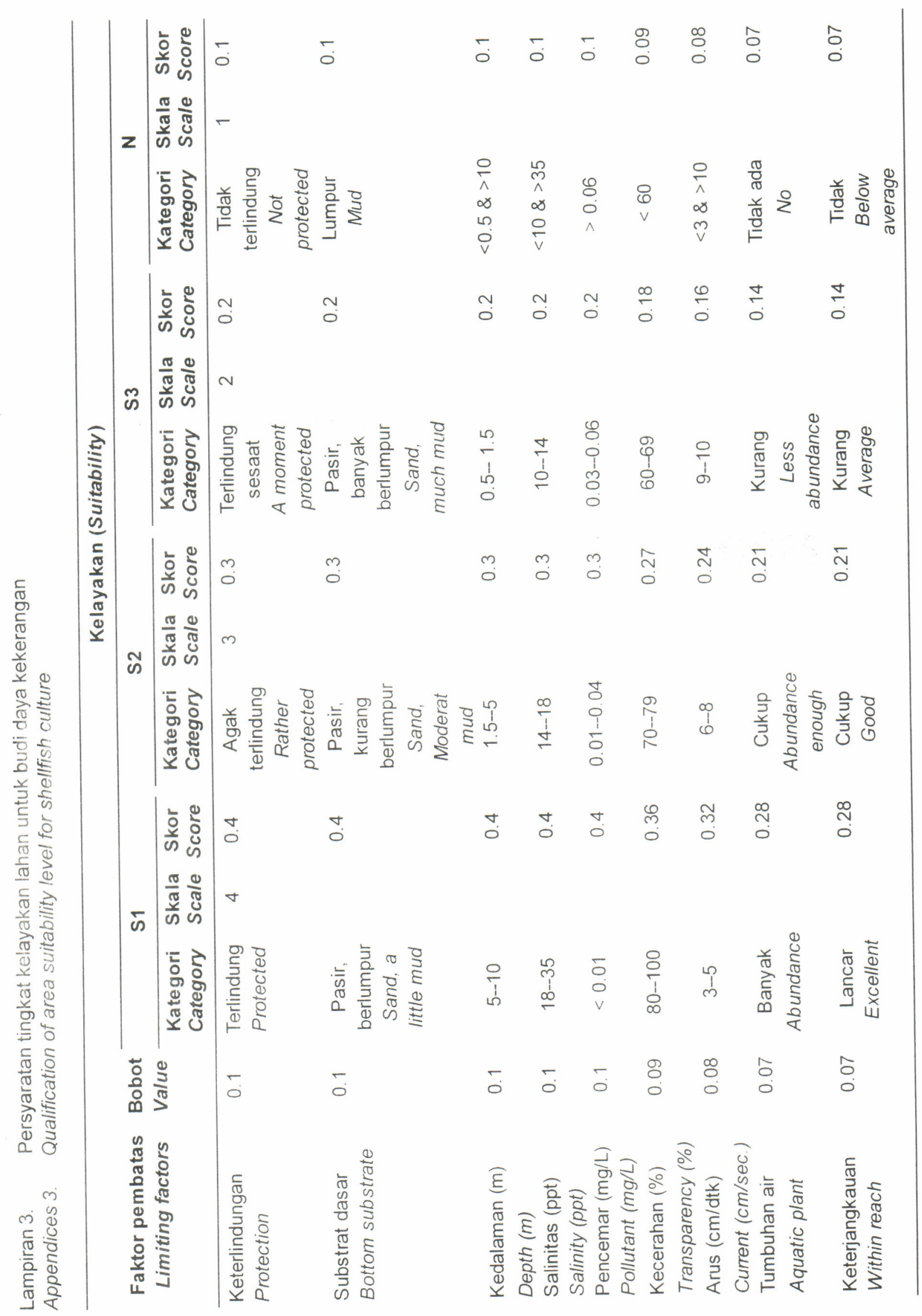




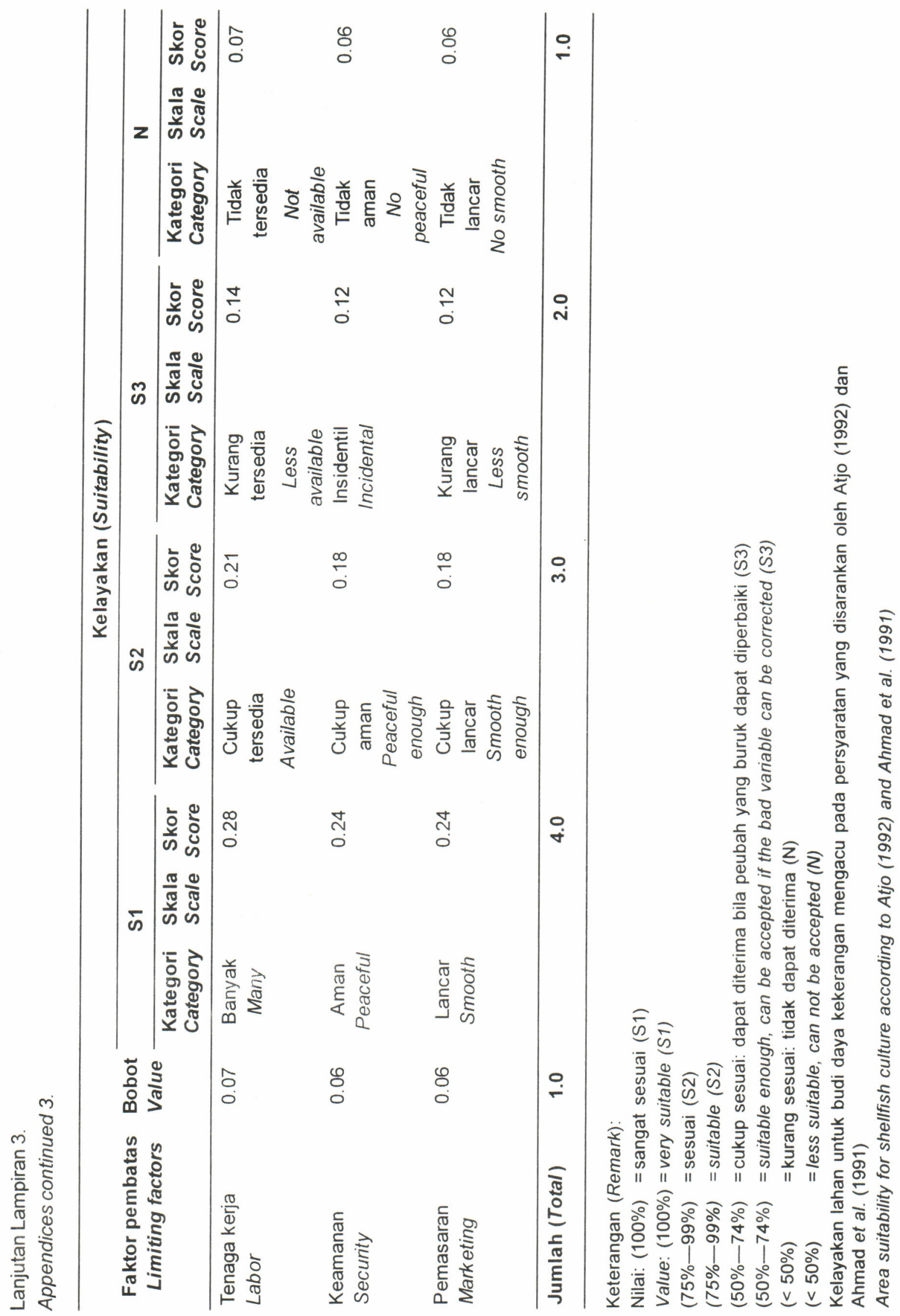


Lampiran 4. Hasil pengukuran fisik dan mutu air Teluk Saleh, Kabupaten Dompu, Nusa Tenggara Barat Appendices 4. Measurement results of physical and water quality of Saleh Bay, Dompu Regency, West

Nusa Tenggara

\begin{tabular}{|c|c|c|c|c|c|c|c|c|}
\hline $\begin{array}{l}\text { Kode } \\
\text { lokasi } \\
\text { Location } \\
\text { code (St) }\end{array}$ & $\begin{array}{c}\text { Posisi } \\
\text { Geografis (UTM) } \\
\text { Geographycal } \\
\text { Position (UTM) }\end{array}$ & $\begin{array}{c}\text { Kecepatan } \\
\text { arus } \\
\text { (cm/detik) } \\
\text { Current } \\
\text { (cm/sec.) }\end{array}$ & $\begin{array}{l}\text { Kedalaman } \\
\text { Depth } \\
\text { (m) }\end{array}$ & $\begin{array}{c}\text { Kecerahan } \\
\text { Transparency } \\
\text { (\%) }\end{array}$ & $\begin{array}{l}\text { Kekeruhan } \\
\text { Turbidity } \\
\text { (NTU) }\end{array}$ & $\begin{array}{l}\text { Pasir } \\
\text { Sand } \\
(\%)\end{array}$ & $\begin{array}{l}\text { Liat } \\
\text { Clay } \\
\text { (\%) }\end{array}$ & $\begin{array}{l}\text { Debu } \\
\text { Silt } \\
(\%)\end{array}$ \\
\hline St 1 & $\begin{array}{l}0609991 \\
9037360 \\
\end{array}$ & 10.5 & 10.2 & 53.9 & 0.8 & 75 & & 20 \\
\hline St 2 & $\begin{array}{l}0609393 \\
9038286 \\
\end{array}$ & 22.7 & 11.9 & 66.2 & 1.32 & 60 & & 40 \\
\hline St 3 & $\begin{array}{l}0607230 \\
9038976 \\
\end{array}$ & 23.8 & 4.2 & 84.2 & 0.88 & 85 & & 15 \\
\hline St 4 & $\begin{array}{l}0607699 \\
9040465 \\
\end{array}$ & 22.7 & 4.1 & 97.6 & 0.23 & 80 & & 19 \\
\hline St 5 & $\begin{array}{l}0605097 \\
9042324 \\
\end{array}$ & 3.3 & 7.6 & 96.2 & 0.9 & 42 & & 58 \\
\hline St 6 & $\begin{array}{l}0606291 \\
9044233 \\
\end{array}$ & 3.2 & 5.2 & 94.5 & 0.25 & 59 & & 41 \\
\hline St 7 & $\begin{array}{l}0610585 \\
9039499 \\
\end{array}$ & 4.2 & 10.2 & 64.1 & 0.54 & 23 & & 69 \\
\hline St 8 & $\begin{array}{l}0611063 \\
9040227 \\
\end{array}$ & 10.6 & 11.6 & 64.3 & 2.07 & 50 & & 50 \\
\hline St 9 & $\begin{array}{l}0611326 \\
9040794 \\
\end{array}$ & 5.7 & 7.9 & 88.6 & 0.21 & 62 & & 35 \\
\hline St 10 & $\begin{array}{l}0610539 \\
9043195 \\
\end{array}$ & 6.5 & 5.8 & 94.8 & 0.11 & 70 & & 26 \\
\hline St 11 & $\begin{array}{l}0609691 \\
9046507\end{array}$ & 8.7 & 22.6 & 77.8 & 0.33 & 53 & & 45 \\
\hline St 12 & $\begin{array}{l}0609475 \\
9045794 \\
\end{array}$ & 23.3 & 25.3 & 73.5 & 2.32 & 29 & & 70 \\
\hline St 13 & $\begin{array}{l}0607227 \\
9048079 \\
\end{array}$ & 5.7 & 7.6 & 72.4 & 3.35 & 42 & & 58 \\
\hline St 14 & $\begin{array}{l}0605462 \\
9048310 \\
\end{array}$ & 9.1 & 21.3 & 69.3 & 2.7 & 69 & & 29 \\
\hline St 15 & $\begin{array}{l}0611657 \\
9038744\end{array}$ & 4.6 & 9.2 & 72.6 & 1.46 & 35 & & 60 \\
\hline
\end{tabular}

Keterangan (Remark):

St :Lokasi pengamatan (Observation location)

UTM : Universal Transverse Merecator (satuan posisi geografis) (Universal Transverse Merecator (value of geographycal position)

Pengambilan sampel air pada kedalaman $4 \mathrm{~m}$ (Water sampling at water depth of $4 \mathrm{~m}$ )

Substrat dasar perairan Teluk Saleh (\%): pasir, liat, dan debu (Bottom substrate of Saleh Bay (\%): sand, clay, and silt) 
Lampiran 5. Hasil pengukuran fisik dan mutu air Teluk Saleh, Kabupaten Dompu, Nusa Tenggara Barat Appendices 5. Measurement results of physical and water quality of Saleh Bay, Dompu Regency, West Nusa Tenggara

\begin{tabular}{ccccccc}
\hline $\begin{array}{c}\text { Salinitas } \\
\text { Salinity } \\
\text { (mg/L) }\end{array}$ & $\mathbf{p H}$ & $\begin{array}{c}\text { Oksigen } \\
\text { terlarut } \\
\text { Disso/ved } \\
\text { oxygen } \\
\text { (mg/L) }\end{array}$ & $\begin{array}{c}\mathbf{N H}_{3}-\mathbf{N} \\
(\mathbf{m g} / \mathbf{L})\end{array}$ & $\begin{array}{c}\mathbf{N O}_{2}-\mathbf{N} \\
(\mathbf{m g} / \mathbf{L})\end{array}$ & $\begin{array}{c}\mathbf{N O}_{3}-\mathbf{N} \\
(\mathbf{m g} / \mathbf{L})\end{array}$ & $\begin{array}{c}\mathbf{P O}_{\mathbf{4}}-\mathbf{P} \\
(\mathbf{m g} / \mathbf{L})\end{array}$ \\
\hline 34.5 & 8.1 & 7.9 & 0.0934 & 0.0144 & 0.1883 & 0.0059 \\
35 & 8.1 & 7.1 & 0.1208 & 0.0176 & 0.0924 & 0.0119 \\
35 & 8.2 & 8.2 & 0.0673 & 0.0168 & 0.0334 & 0.0213 \\
35 & 8.3 & 8.0 & 0.1052 & 0.0261 & 0.1127 & 0.0177 \\
34.5 & 8.2 & 7.8 & 0.0843 & 0.0122 & 0.0378 & 0.0106 \\
35 & 8.3 & 8.0 & 0.1039 & 0.0177 & 0.1084 & 0.0224 \\
35 & 8.4 & 7.1 & 0.0662 & 0.0161 & 0.0906 & 0.0289 \\
34.5 & 8.3 & 7.8 & 0.0735 & 0.0126 & 0.0471 & 0.0300 \\
35 & 8.3 & 7.5 & 0.1002 & 0.0102 & 0.0931 & 0.0212 \\
34.5 & 8.3 & 7.7 & 0.0520 & 0.0130 & 0.0773 & 0.0314 \\
35 & 8.3 & 7.6 & 0.0998 & 0.0204 & 0.0387 & 0.0268 \\
35 & 8.3 & 7.4 & 0.1270 & 0.0166 & 0.0470 & 0.0321 \\
35 & 8.3 & 8.1 & 0.0637 & 0.0123 & 0.0777 & 0.0280 \\
35 & 8.3 & 7.0 & 0.0855 & 0.0104 & 0.0309 & 0.0325 \\
35 & 8.3 & 7.2 & 0.0611 & 0.0148 & 0.1364 & 0.0269 \\
\hline
\end{tabular}


Lampiran 6. Hasil analisis logam berat di perairan Teluk Saleh, Kabupaten Dompu, Nusa Tenggara Barat Appendices 6. Analysis resulted of heavy metal in Saleh Bay, Dompu Regency, West Nusa Tenggara

\begin{tabular}{ccccc}
\hline $\begin{array}{c}\text { Kode } \\
\text { lokasi } \\
\text { Location } \\
\text { code }\end{array}$ & $\begin{array}{c}\text { Kadmium (Cd) } \\
\text { Cadmium (Cd) } \\
\text { (mg/L) }\end{array}$ & $\begin{array}{c}\text { Tembaga (Cu) } \\
\text { Cuprum (Cu) } \\
\text { (mg/L) }\end{array}$ & $\begin{array}{c}\text { Timbal (Pb) } \\
\text { Plumbum (Pb) } \\
\text { (mg/L) }\end{array}$ & $\begin{array}{c}\text { Seng (Zn) } \\
\text { Zinc (Zn) } \\
\text { (mg/L) }\end{array}$ \\
\hline St 1 & 0.0035 & 0.0023 & 0.0089 & 0.0421 \\
St 2 & 0.0038 & 0.0010 & 0.0087 & 0.0385 \\
St 3 & 0.0036 & 0.0019 & 0.0093 & 0.0527 \\
St 4 & 0.0035 & 0.0003 & 0.0090 & 0.0361 \\
St 5 & 0.0037 & 0.0032 & 0.0088 & 0.0443 \\
St 6 & 0.0036 & 0.0015 & 0.0095 & 0.0576 \\
St 7 & 0.0035 & 0.0037 & 0.0087 & 0.0492 \\
St 8 & 0.0036 & 0.0008 & 0.0096 & 0.0364 \\
St 9 & 0.0039 & 0.0022 & 0.0089 & 0.0634 \\
St 10 & 0.0037 & 0.0041 & 0.0092 & 0.0405 \\
St 11 & 0.0035 & 0.0016 & 0.0089 & 0.0387 \\
St 12 & 0.0038 & 0.0045 & 0.0094 & 0.0365 \\
St 13 & 0.0036 & 0.0009 & 0.0087 & 0.0422 \\
St 14 & 0.0035 & 0.0028 & 0.0091 & 0.0393 \\
St 15 & 0.0037 & 0.0011 & 0.0090 & 0.0378 \\
\hline
\end{tabular}


Lampiran 7. Sebaran stasiun pengamatan untuk kelayakan budi daya laut di Teluk Saleh, Dompu, Nusa Tenggara Barat

Appendices 7. Distribution of station observation for suitable marine culture in Saleh Bay, Dompu, West Nusa Tenggara

PETA SEBARAN TITIK SAMPLING PADA LOKASI PENELITIAN DISTRIBUTION MAP OF SAMPLING POINT IN RESEARCH LOCATION

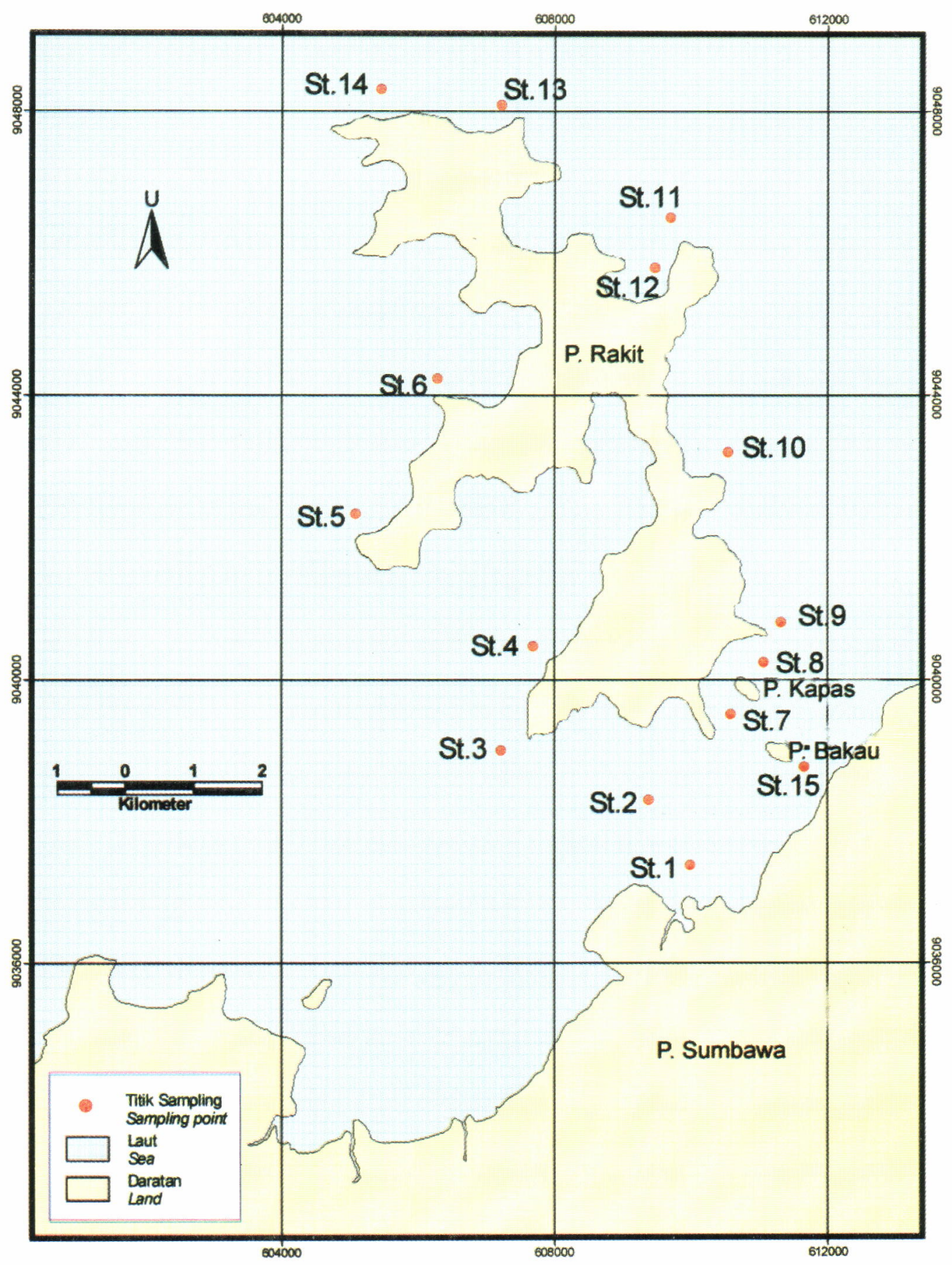


Lampiran 8. Peta kelayakan lahan budi daya laut di Teluk Saleh, Dompu, Nusa Tenggara Barat Appendices 8. Map of suitable areas for marine culture in Saleh Bay waters, Dompu, NTB

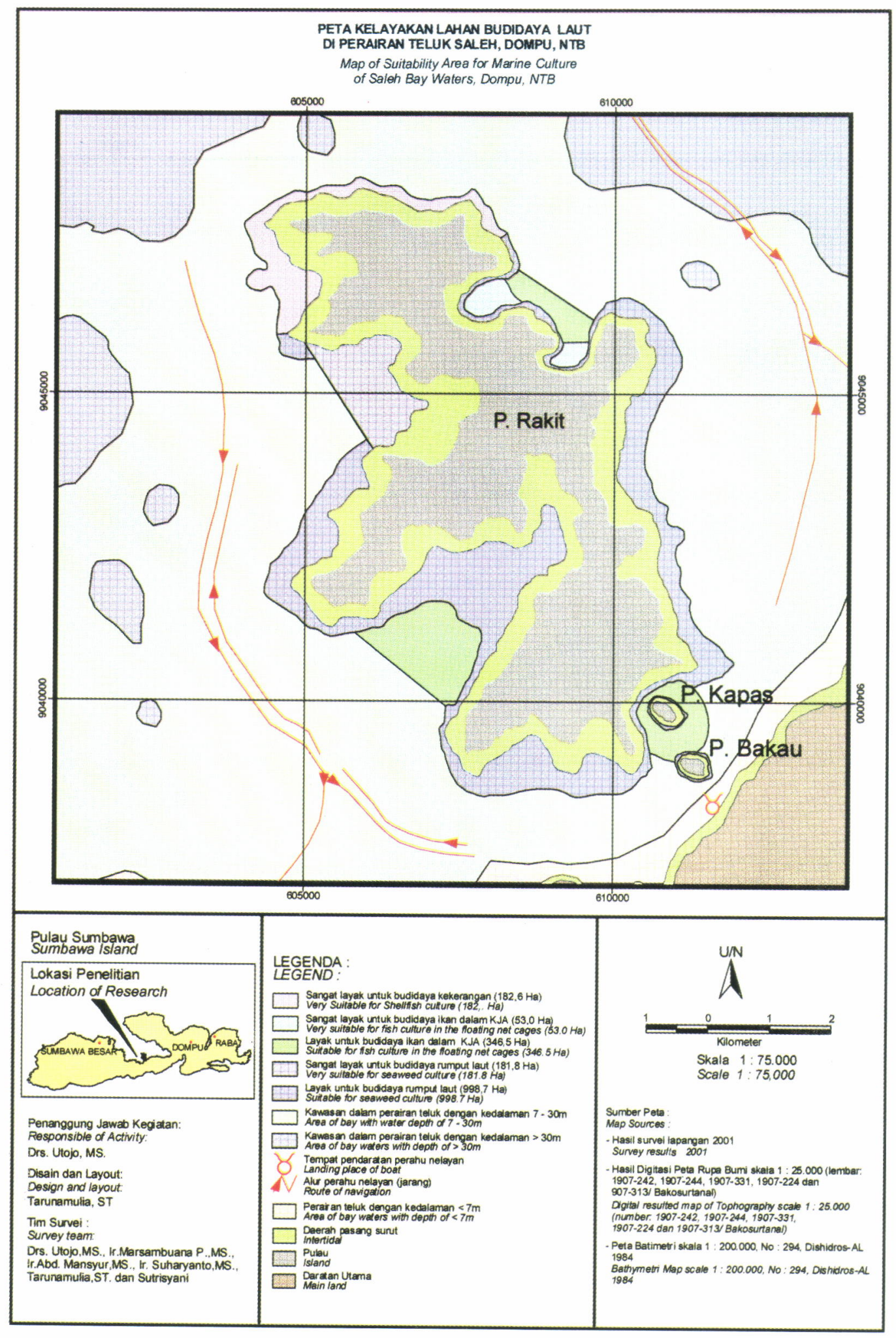

